\title{
Effect of Dilution of Treated Distillery Effluent (TDE) on Soil Properties and Yield of Sugarcane
}

\author{
Previna Sivaloganathan", Baskar Murugaiyan, Saravanan Appavou, Leninraja Dharmaraj \\ Department of Soil Science and Agricultural Chemistry, Anbil Dharmalingam Agricultural College and Research Institute, Trichira- \\ palli, India. \\ Email: "previyuti@gmail.com
}

Received June $16^{\text {th }}$, 2013; revised July $17^{\text {th }}$, 2013; accepted August $19^{\text {th }}, 2013$

Copyright (c) 2013 Previna Sivaloganathan et al. This is an open access article distributed under the Creative Commons Attribution License, which permits unrestricted use, distribution, and reproduction in any medium, provided the original work is properly cited.

\begin{abstract}
Sugarcane is one of the most important cash crops, which plays a pivotal role in India's agricultural and industrial economy. The treated distillery effluent (TDE) being plant originated, contains all plant nutrients and organic matter. Therefore, it is being used as a cheap source of nutrients and organic manure in agriculture activities in soil besides improving soil physical properties. The experiment was conducted during August, 2010-2011 and 2011-2012 with CO 86032 in a randomized block design with six treatments and was replicated four times. The TDE was discharged @ 1.00, 0.50, $0.33,0.25$ and 0.20 lakh liters ha $^{-1}$ to get the dilutions of 1:10, 1:20, 1:30, 1:40 and 1:50 dilutions respectively. It was applied four times at 40 days interval starting from 45th day after planting. The fertilizers viz., N and P @ 75 percent of the recommended dose were applied and $\mathrm{K}$ was skipped. The results revealed that irrigation with TDE at 1:10 dilution resulted in higher yield of sugarcane. The TDE did not have any influence on quality parameters of sugarcane. The TDE application favourably influenced the available nutrients and organic carbon content in the soil. Besides, the present findings credibly proved that the TDE application not only enhanced the soil fertility status but also substituted for 25 percent of $\mathrm{N}$ and $\mathrm{P}$ and 100 percent of $\mathrm{K}$ fertilizers to sugarcane crop.
\end{abstract}

Keywords: TDE; Dilution; Sugarcane; Yield; Soil Properties

\section{Introduction}

Molasses based distillery units discharge large quantities of effluent and these units face problems in the disposal of effluent. This effluent has high percentage of organic materials, which have high percentage of biological oxygen demand (BOD) $\left(90,000\right.$ to $\left.100,000 \mathrm{mg} \cdot \mathrm{L}^{-1}\right)$. Indiscriminate disposal of the effluent in water and on dilution land leads to serious pollution and changes the nutrient and biological status of the soil where they are disposed of. So it should be diluted with irrigation water and then applied to growing crops. Technology has been developed to use this effluent as fertigation source to crops like sugarcane, sunflower etc., after diluting it with irrigation water to reduce the BOD level in the ratios of 1:10 to $1: 50$. The present study was undertaken with a view to study the effect of treated distillery effluent on the sugarcane yield and quality and also their nutrient status in the soil.

"Corresponding author.

\section{Materials and Methods}

\subsection{Experimental Site}

The research was conducted with application of TDE through irrigation water during off season of 2010-2011 and 2011-2012 at experimental site of M/s EID Parry (I) Ltd., cane farm, Edayanvelli, Cuddalore district, Tamil Nadu. The experimental site lies geographically in between $11^{\circ} 46^{\prime}$ and $19^{\circ} 6^{\prime}$ North Latitude and $79^{\circ} 40^{\prime}$ and $5^{\circ} 1^{\prime}$ East Longitude and at an altitude of 62 metres above mean sea level. Trail was conducted with sandy loam in texture and the soil, the intial soil pH was 8.40, ESP 11.2 per cent and EC $0.10 \mathrm{dS} \cdot \mathrm{m}^{-1}$. The soil organic carbon content was 0.50 per cent and the soil available $\mathrm{N}$ was low in status, whereas available $\mathrm{P}$ and $\mathrm{K}$ were medium in status (Table 1). The treated distillery effluent (TDE) used in this study was collected from the molasses based distillery industry M/s EID Parry India Ltd., Nellikuppam, Cuddalore District, Tamil Nadu (Table 2). It was analysed for various physic-chemical properties. 
Table 1. Characteristics of treated distillery effluent (TDE).

\begin{tabular}{cccc}
\hline Parameters & Values & Parameters & Values (ppm) \\
\hline pH & 7.3 & $\begin{array}{c}\text { Organic carbon } \\
\text { (percent) }\end{array}$ & 27.4 \\
EC (dS· ${ }^{-1}$ ) & 29.5 & Nitrogen & 1350 \\
BOD & 4500 & Phosphorus & 550 \\
COD & 48,000 & Potassium & 9500 \\
$\begin{array}{c}\text { Total solids } \\
(\text { ppm) }\end{array}$ & 85,000 & Sulphates & 4650 \\
$\begin{array}{c}\text { Suspended solids } \\
\text { (ppm) }\end{array}$ & 8400 & Sodium & 456 \\
$\begin{array}{c}\text { Dissolved solids } \\
\text { (ppm) }\end{array}$ & 55,000 & Calcium & 2345 \\
$\begin{array}{c}\text { Magnesium } \\
\text { (ppm) }\end{array}$ & 2406 & Copper & 65 \\
Zinc & 11 & Iron & 4.3 \\
\hline
\end{tabular}

Values are in $\mathrm{mg} \cdot \mathrm{L}^{-1}$ unless otherwise stated.

Table 2. Characteristics of experimental soil.

\begin{tabular}{|c|c|c|}
\hline S No & Parameter & Values \\
\hline 1. & Soil Series & Vadalapakkam \\
\hline 2. & Soil taxonomy & Typic Haplustalf \\
\hline 3. & Texture & Sandy loam \\
\hline 4. & Bulk density $\left(\mathrm{Mg} \cdot \mathrm{m}^{-3}\right)$ & 1.32 \\
\hline 5. & Particle density $\left(\mathrm{Mg} \cdot \mathrm{m}^{-3}\right)$ & 2.33 \\
\hline 6. & Pore space (\%) & 30.2 \\
\hline 7. & Water holding capacity (\%) & 36.4 \\
\hline 8. & $\mathrm{pH}$ & 8.38 \\
\hline 9. & $\mathrm{EC}\left(\mathrm{dS} \cdot \mathrm{m}^{-1}\right)$ & 0.10 \\
\hline 10. & CEC $\left(\mathrm{cmol} \mathrm{p}(+) \mathrm{kg}^{-1}\right.$ & 15.6 \\
\hline 11. & Organic carbon (per cent) & 0.37 \\
\hline 12. & Available $\mathrm{N}\left(\mathrm{kg} \cdot \mathrm{ha}^{-1}\right)$ & 123 \\
\hline 13. & Available P $\left(\mathrm{kg} \cdot \mathrm{ha}^{-1}\right)$ & 15.1 \\
\hline 14. & Available $\mathrm{K}\left(\mathrm{kg} \cdot \mathrm{ha}^{-1}\right)$ & 212 \\
\hline 15. & $\begin{array}{l}\text { Exchangeable Calcium } \\
\quad\left(\mathrm{cmol}\left(\mathrm{p}^{+}\right) \mathrm{kg}^{-1}\right)\end{array}$ & 7.40 \\
\hline 16. & $\begin{array}{l}\text { Exchangeable Magnesium } \\
\qquad\left(\mathrm{cmol}\left(\mathrm{p}^{+}\right) \mathrm{kg}^{-1}\right)\end{array}$ & 3.50 \\
\hline 17. & $\begin{array}{l}\text { Exchangeable Sodium } \\
\quad\left(\mathrm{cmol}\left(\mathrm{p}^{+}\right) \mathrm{kg}^{-1}\right)\end{array}$ & 1.52 \\
\hline 18. & $\begin{array}{l}\text { Exchangeable Potassium } \\
\quad\left(\mathrm{cmol}\left(\mathrm{p}^{+}\right) \mathrm{kg}^{-1}\right)\end{array}$ & 0.25 \\
\hline 19. & ESP (\%) & 12.0 \\
\hline
\end{tabular}

\subsection{Experimental Design and Treatment Details}

The experiment was conducted in a randomized block design with six treatments viz., control $\left(\mathrm{T}_{1}\right) ; 1: 10$ dilution $\left(T_{2}\right)$; 1:20 dilution $\left(T_{3}\right)$; 1:30 dilution $\left(T_{4}\right)$ 1:40 dilution $\left(T_{4}\right)$ and 1:50 dilution $\left(T_{5}\right)$. The treated distillery effluent was discharged at the rate of $1.00,0.50,0.33,0.25$ and 0.20 lakh litres $\mathrm{ha}^{-1}$ to get the dilutions of $1: 10,1: 20$, 1:30, 1:40 and 1:50 respectively. The diluted treated distillery effluent was applied four times at 40 days interval starting from 45th day after planting. The $\mathrm{N}$ and $\mathrm{P}$ fertilizers were applied at the rate of 75 percent of the recommended dose. $\mathrm{K}$ was skipped from the fertilizer schedule. The soil and plant samples were collected at harvest stage and assessed for the availability of nutrients in soil, apart from the yield and quality parameters.

\subsection{Statistical Analysis}

The data were statistically analysed following the procedure [1] for randomized block design. Whenever significant difference existed, critical difference was constructed at five per cent probability level. Such of those treatments where the difference are not significant are denoted as NS.

\section{Results and Discussion}

\subsection{Effect of Soil pH}

The soil $\mathrm{pH}$ was changed towards near neutral from the initial value of 8.35. The $\mathrm{pH}$ declined from 8.38 in control $\left(\mathrm{T}_{1}\right)$, to $7.85,7.88,7.98,8.10$ and 8.19 due to the TDE application at the rate of 1:10 $\left(\mathrm{T}_{2}\right), 1: 20\left(\mathrm{~T}_{3}\right), 1: 30$ $\left(T_{4}\right), 1: 40\left(T_{5}\right)$ and 1:50 $\left(T_{6}\right)$ respectively. However, the differences were not significant. The application of different dilutions of TDE did not affect the soil $\mathrm{pH}$ significantly (Table 3). Since the distillery effluent contained appreciable amount of basic cations and organic matter, its application to soil might have a direct impact on the physico-chemical properties of soil. The supply of $\mathrm{Ca}^{2+}$ and $\mathrm{Mg}^{2+}$ by treated distillery effluent might have influenced the $\mathrm{pH}$ of soil and maintained around neutral.

\subsection{Effect of Soil EC}

The EC of the post harvest soil was increased from the initial value of 0.10 to $0.37 \mathrm{dS} \cdot \mathrm{m}^{-1}$ due to the application of TDE at 1:10 dilution $\left(\mathrm{T}_{2}\right)$. Though the EC of the soil increased due to application of TDE, the EC of the TDE applied soil was well within the safer limit (Table 4). The soluble salt content measured in the experiment showed that the salt accumulation was leached because of 10 to 40 irrigations and also due to precipitation of monsoon and sandy loam in texture. Thus the EC of the soil was maintained within the safe limits up to TDE at 
Table 3. Effect of TDE at different dilutions on chemical properties of soil.

\begin{tabular}{lccc}
\hline Treatments & $\mathbf{p H}$ & $\mathbf{E C}$ & OC \\
\hline & & $\left(\mathbf{d S} \cdot \mathbf{m}^{-1}\right.$ ) & (percent) \\
$\mathrm{T}_{1}$-Control & 8.38 & 0.12 & 0.46 \\
$\mathrm{~T}_{2}-1: 10 \mathrm{~T}$ dilution & 8.01 & 0.36 & 0.89 \\
$\mathrm{~T}_{3}-1: 20 \mathrm{~T}$ dilution & 8.06 & 0.33 & 0.83 \\
$\mathrm{~T}_{4}-1: 30$ T dilution & 8.12 & 0.28 & 0.75 \\
$\mathrm{~T}_{5}-1: 40$ T dilution & 8.17 & 0.29 & 0.75 \\
$\mathrm{~T}_{6}-1: 50 \mathrm{~T}$ dilution & 8.19 & 0.26 & 0.74 \\
$\mathrm{SE} \mathrm{d}$ & 0.23 & 0.01 & 0.03 \\
$\mathrm{CD}(0.05)$ & $\mathrm{NS}$ & $\mathrm{NS}$ & 0.06 \\
\hline
\end{tabular}

Table 4. Effect of TDE at different dilutions on chemical properties of soil.

\begin{tabular}{cccc}
\hline Treatments & $\begin{array}{c}\text { Alkaline } \\
\text { KMnO }_{4}-\mathbf{N}\end{array}$ & $\begin{array}{c}\mathbf{0 . 5} \mathbf{~ M} \\
\mathbf{N a H C O}_{3}-\mathbf{P}\end{array}$ & $\begin{array}{c}\text { Neutral Normal } \\
\text { mmonium } \\
\text { Acetate-K }\end{array}$ \\
\hline & & $\mathbf{( k g \cdot \mathbf { h a } ^ { - 1 } \text { ) }}$ & \\
$\mathrm{T}_{1}$-Control & 230 & 17.7 & 268 \\
$\mathrm{~T}_{2}-1: 10 \mathrm{~T}$ dilution & 286 & 28.3 & 510 \\
$\mathrm{~T}_{3}-1: 20$ T dilution & 272 & 26.4 & 479 \\
$\mathrm{~T}_{4}-1: 30$ T dilution & 265 & 24.8 & 460 \\
$\mathrm{~T}_{5}-1: 40$ T dilution & 261 & 24.0 & 448 \\
$\mathrm{~T}_{6}-1: 50$ T dilution & 256 & 23.6 & 434 \\
SE d & 6 & 1.1 & 12 \\
CD $(0.05)$ & 14 & 2.3 & 25 \\
\hline
\end{tabular}

the rate of 1.0 lakh litres $\cdot \mathrm{ha}^{-1}$ application. It also noted that an increase in soil EC but within the safe limit of 1.0 $\mathrm{dS} \cdot \mathrm{m}^{-1}$ due to the application of distillery effluent, which support the findings of the present study $[2,3]$.

\subsection{Effect of Organic Carbon}

The organic carbon content of the soil had significantly increased corresponding to the quantity of TDE added through irrigation water (Table 4). The organic carbon content of soil was found to be increasing significantly at 1:10/1:20 dilutions and further dilutions proved to have decreased organic carbon values. The increase in organic carbon also might be due to decomposition and humification of organic matter in soil supplied through TDE.

\subsection{Effect of Alkaline $\mathrm{KMnO}_{4}-\mathrm{N}$}

The supply of TDE (four times per year) resulted in sig- nificant build up in available $\mathrm{N}$ content at post harvest soil. Increase in rate of TDE application, increased the alkaline $\mathrm{KMnO}_{4}-\mathrm{N}$ content of the soil (Table 4). Though the TDE application had significant positive effect on alkaline $\mathrm{KMnO}_{4}-\mathrm{N}$ as compared to control, the graded dilutions did not produce any spectacular variations amongst themselves. This might be due to the addition of organic matter in the form of TDE would have provided the source of $\mathrm{N}$ for the multiplication of microbes and subsequent increase in the nutrient availability during the decomposition as observed in sugarcane [4].

\subsection{Effect of $0.5 \mathrm{M} \mathrm{NaHCO}_{3}-\mathrm{P}$}

The $0.5 \mathrm{M} \mathrm{NaHCO}_{3}-\mathrm{P}$ in post harvest soil was found to be influenced by TDE application (Table 4). The highest $0.5 \mathrm{M} \mathrm{NaHCO}_{3}-\mathrm{P}$ recorded in 1:10 $\left(\mathrm{T}_{2}\right)\left(27.9 \mathrm{~kg} \cdot \mathrm{ha}^{-1}\right)$ whereas lowest in control $\left(\mathrm{T}_{1}\right)\left(17.7 \mathrm{~kg} \cdot \mathrm{ha}^{-1}\right)$. Though TDE was not acidic, the decomposition processes of easily degradable organics might have reduced the binding energy and P sorption capacity of the soil, favouring higher $\mathrm{P}$ availability in the soil. Similar results were reported [5,6].

\subsection{Effect of Neutral Normal Ammonium Acetate-K}

The neutral normal ammonium acetate-K content in all the treatments was increased by TDE (Table 4). The highest value was noticed in 1:10 $\left(\mathrm{T}_{2}\right)\left(499 \mathrm{~kg} \cdot \mathrm{ha}^{-1}\right)$ whereas lowest in control $\left(272 \mathrm{~kg} \cdot \mathrm{ha}^{-1}\right)$. However, the increase in soil neutral normal ammonium acetate-K was not significant beyond the dilution of 1:20 $\left(\mathrm{T}_{3}\right)$. The available $\mathrm{K}$ in the soil got increased 4 to 5 times due to the TDE irrigation which might be due to the fact that $\mathrm{K}$ was one of the components supplied in larger quantities [7].

\subsection{Effect of Cane Yield}

The sugarcane yield was remarkably increased with the application of TDE together with irrigation water at different dilutions compared to control (Table 5). The highest cane yield $\left(115 \mathrm{t} \cdot \mathrm{ha}^{-1}\right)$ was recorded in the plots which received 1:10 dilutions $\left(T_{2}\right)$, whereas lowest yield was noticed in control plot $\left(78 \mathrm{t} \cdot \mathrm{ha}^{-1}\right)$ at post harvest soil. The nutrient addition by TDE through frequent irrigation leading to continuous and steady availability of nutrients. Similar increases in sugarcane yields for TDE application through irrigations were earlier reported by $[8,9]$.

\subsection{Effect of Quality Parameters}

The quality parameters viz., brix, pol, purity and CCS per cent were found to be numerically higher in the plots which received TDE at 1:10 dilution $(18.27,16.40,89.76$ and 11.74 percent) and the control $\left(\mathrm{T}_{1}\right)$ recorded the low- 
Table 5. Effect of TDE at different dilutions on cane yield $\left(\mathrm{t} \cdot \mathrm{ha}^{-1}\right)$ and quality parameters of sugarcane.

\begin{tabular}{|c|c|c|c|c|c|c|}
\hline Treatments & Yield $\left(t \cdot h a^{-1}\right)$ & Brix (\%) & Pol (\%) & Purity (\%) & CCS (\%) & Sugar yield $\left(t \cdot h^{-1}\right)$ \\
\hline $\mathrm{T}_{1}$-Control & 78.0 & 18.04 & 16.17 & 89.63 & 11.57 & 9.02 \\
\hline $\mathrm{T}_{2}-1: 10 \mathrm{~T}$ dilution & 115.0 & 18.27 & 16.40 & 89.76 & 11.74 & 13.50 \\
\hline $\mathrm{T}_{3}-1: 20 \mathrm{~T}$ dilution & 110.0 & 18.25 & 16.38 & 89.75 & 11.72 & 12.89 \\
\hline $\mathrm{T}_{4}-1: 30 \mathrm{~T}$ dilution & 102.0 & 18.22 & 16.35 & 89.74 & 11.70 & 11.93 \\
\hline $\mathrm{T}_{5}-1: 40 \mathrm{~T}$ dilution & 96.0 & 18.20 & 16.33 & 89.73 & 11.69 & 11.22 \\
\hline $\mathrm{T}_{6}-1: 50 \mathrm{~T}$ dilution & 90.0 & 18.20 & 16.33 & 89.73 & 11.69 & 10.52 \\
\hline SE d & 2.8 & 0.25 & 0.24 & 1.40 & 0.23 & 0.05 \\
\hline $\mathrm{CD}(0.05)$ & 6.1 & NS & NS & NS & NS & 0.10 \\
\hline
\end{tabular}

est (18.04, 16.17, 89.63 and 11.57 percent) respectively (Table 5). The treatment effect did not influence the quality parameters of the cane. The treatment of graded doses of TDE did not influence on quality parameters. Similar findings were also reported by [5].

\section{Conclusion}

Based on the above results, the TDE could be beneficially recycled in sandy loam soil at 1:10 dilution for getting higher cane yield and enhanced soil fertility. Besides, the present findings credibly proved that the TDE application not only enhanced the soil fertility status but also substituted for 25 percent of $\mathrm{N}$ and $\mathrm{P}$ and 100 per cent of $\mathrm{K}$ fertilizers to sugarcane crop. This reduction in fertilizer cost has directly increased the benefit: cost ratio and has resulted in higher remuneration. Since there was no sign of environmental pollution as to either crop growth or the soil health at any point of time due to effluent application, it can be recycled judiciously in agriculture for enhancing crop production.

\section{Acknowledgements}

We wish to express their gratitude to M/s EID Parry (I) Limited, Nellikuppam, Cuddalore district, Tamil Nadu for providing financial support to this study.

\section{REFERENCES}

[1] K. A. Gomez and A. A. Gomez, "Statistical Procedures for Agricultural Research,” John Wiley and Sons, New Delhi, 2010, p. 680.
[2] H. C. Joshi, H. Pathak, A. Choudhary and N. Kalra, "Distillery Effluent as a Source of Plant Nutrients,” Fertilizer News, Vol. 41, 1996, pp. 41-47.

[3] K. Selvakumar, "Impact of Post-Methanated Distillery Spentwash on the Yield and Quality of Sweet Sorghum and on Soil Health,” M.Sc. Thesis, Tamil Nadu Agricultural University, Coimbatore, 2006, pp. 122-126.

[4] G. C. Satisha, "Bioconversion of Sugar Industrial Effluent Wastes into Enriched Compost and Its Effect on Soils and Crops," Ph.D. Thesis, Tamil Nadu Agricultural University, Coimbatore, 2000, p. 145.

[5] R. Pushpavalli, P. Kotteeswaran, M. Krishnamurthi and P. Parameswaran, "Effect of Treated Distillery Effluent Application on Soil and Yield of Sugarcane at Nellikuppam in Tamil Nadu, India," Second International Conference on Contaminants in the Soil Environment in the AustraliaPacific Region, New Delhi, 12-17 December, 1999, p. 103.

[6] R. Murugaragavan, "Distillery Spentwash on Crop Production in Dryland Soils,” M.Sc. Thesis, Tamil Nadu Agricultural University, Coimbatore, 2002, pp. 145-165.

[7] D. Dinesh, "Utilization of Distillery Industrial Wastes as Sources of Nutrients for Maize (Zea mays L.)," Ph.D. Thesis, Tamil Nadu Agricultural University, Coimbatore, 2011, pp. 67-69.

[8] L. Devarajan, G. Rajannan, G. Ramanathan and G. Oblisami, "Sugarcane Cultivation with Distillery Effluent," South Indian Sugarcane and Sugar Technologist Association-Sugar Journal, Vol. 20, 1993, pp. 23-25.

[9] D. Janaki, "Utilization of Distillery Spentwash as Manure to Crops and Its Impact on Soil, Crop and Ground Water Quality,” Ph.D. Thesis, Tamil Nadu Agricultural University, Coimbatore, 2008, pp. 56-64. 